\title{
Shifting submarine canyons and development of a foreland basin in SW Taiwan: controls of foreland sedimentation and longitudinal sediment transport
}

\author{
Ho-Shing $\mathrm{Yu}^{\mathrm{a}, *}$, Eason Hong ${ }^{\mathrm{b}}$ \\ ${ }^{a}$ Institute of Oceanography, National Taiwan University, Taipei, Taiwan, ROC \\ ${ }^{\mathrm{b}}$ Department of Oceanography, National Taiwan Ocean University, Keelung, Taiwan
}

Received 30 June 2004; received in revised form 17 August 2005; accepted 15 September 2005

\begin{abstract}
The modern Penghu Submarine Canyon is a sea floor expression of the convergent boundary between the frontal Taiwan orogenic wedge and the Chinese cratonic margin. The canyon is about $180 \mathrm{~km}$ long and trends N-S, parallel to the strike of the Taiwan mountain belt. It is $\sim 240 \mathrm{~m}$ deep at the head increasing to $\sim 3200 \mathrm{~m}$ deep at its mouth before merging gradually into the Manila Trench.

The Penghu Canyon is considered a tectonically controlled canyon rather than a slope canyon dominated by down-slope processes. Tectonic controls prevail over sedimentary processes. Tectonics controls the orientation and location of the Penghu Canyon while sedimentary processes contribute to its excavation and enlargement. The axis of the deep-water, underfilled basin off SW Taiwan dips southward and parallels the strike of the Taiwan orogen with a characteristic longitudinal sediment transport route. Hence, the Penghu Canyon developed under the gravitational mass movement with its main course along the N-S basin axis, not in a SW or SE downslope direction of both margins. The initial Penghu Canyon began at the intersection of the upper slopes of the South China Sea and Kaoping Slopes. Sediment flows cut into the slope sediments following regional dip toward the south, and excavated along the deepest part of the sea floor, forming the present Penghu Canyon.

Shifting of axes of Late Pliocene-Pleistocene canyons from onshore SW Taiwan to the present-day position of the Penghu Canyon reflects the evolving foreland basins with a longitudinal canyon transport system progressively migrating southwestward. The linkage of canyon migration and evolution of the foreland basin may have significant implications for the overall sedimentation and tectonics of the SW Taiwan region. (C) 2005 Elsevier Ltd. All rights reserved.
\end{abstract}

\section{Introduction}

The offshore area of SW Taiwan consists of a very narrow Kaoping Shelf $(\sim 10 \mathrm{~km})$ and a broad Kaoping Slope that extends to about $3000 \mathrm{~m}$ deep before merging westward into the South China Sea Slope in the northern tip of the South China Sea basin (Fig. 1). The sea floor between SW Taiwan and SE China is characterized by two deep-water submarine slopes facing each other (Fig. 1).

Numerous gullies and canyons have developed on the Kaoping and South China Sea Slopes (Fig. 1). The courses of these canyons are generally oriented SW or SE, normal or oblique to the shorelines with the exception of the Penghu

\footnotetext{
* Corresponding author

E-mail address: yuhs@ntu.edu.tw (H.-S. Yu).
}

Canyon. Most of the canyons are slope features with heads initiated at the upper slopes, below the shelfbreak (Shepard, 1981; Pratson and Coakley, 1996). However, the Penghu Canyon is distinguished by its location and orientation, in a north-south direction along the boundary between the South China Sea and the Kaoping Slopes (Fig. 1). The Penghu Canyon has tributaries on both continental slopes. All canyons are formed by downslope erosion of the sea floor on active as well as passive margins. The major difference is that tectonics controls the location and orientation of a canyon while sedimentary processes contribute to the excavation and enlargement of the canyon. For example, McHugh et al. (1998) showed that the path of the Monterey Submarine Canyon makes a sharp bend from WNW to SSW $(1800 \mathrm{~m})$ where it is crossed by the San Gregorio fault. Sediment flows lead to extensive failure and mass-wasting at the head and on the lower walls of the Monterey Canyon 


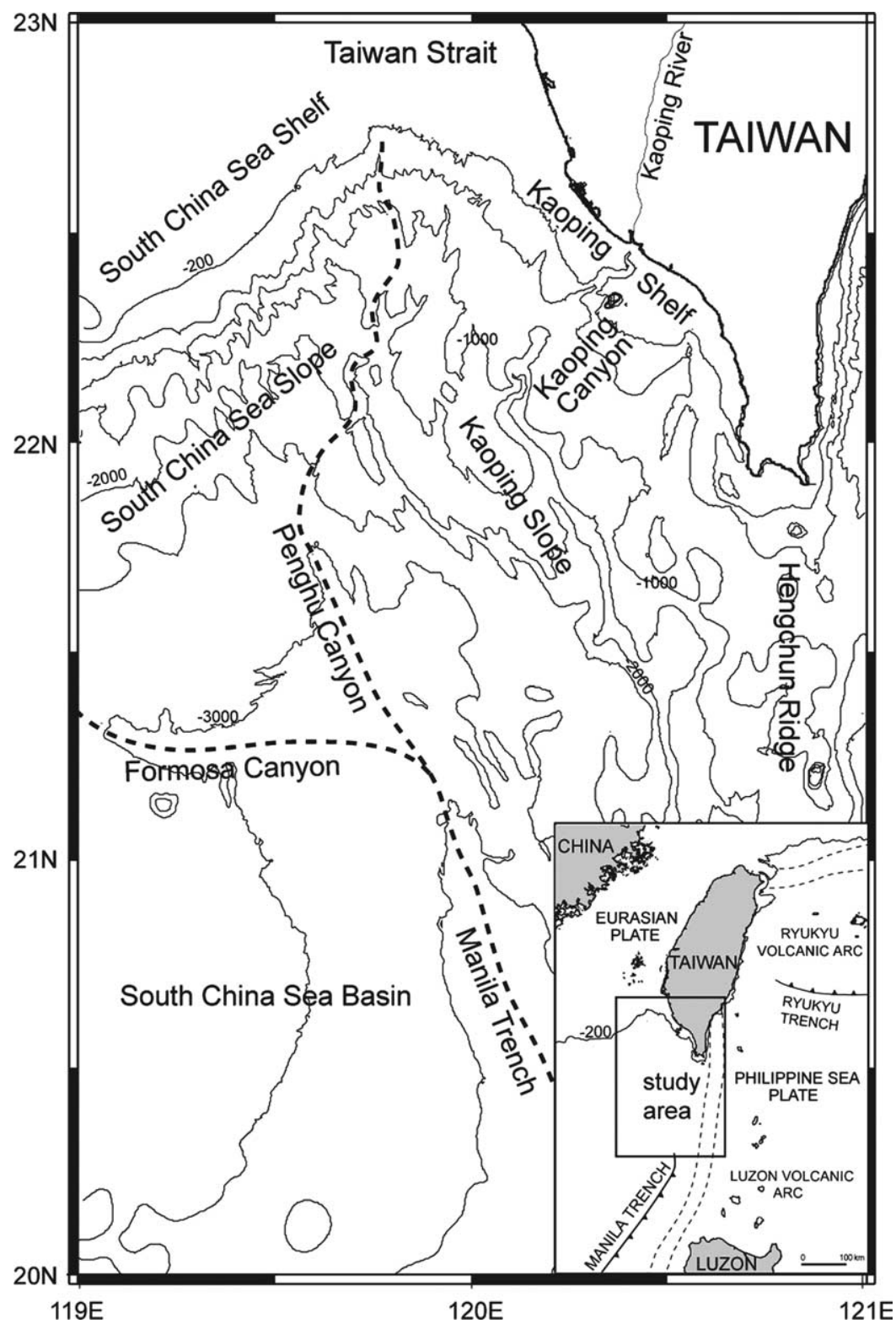

Fig. 1. Bathymetric map showing that the sea floor of the marine basin off southwestern Taiwan consists of two broad and deep slopes marked by outward bowing bathymetric contours. The South China Sea Slope on the Chinese cratonic side mainly dip southeast but the Kaoping Slope on the Taiwan orogen side dips southwest. These two slopes converge in the north and gradually merge into the Taiwan Strait shelf. The boundary separating these two submarine slopes is the Penghu Canyon marked by a dotted line and located along the basin bottom. The Penghu Canyon extends nearly in a N-S direction parallel to the strike of the Taiwan orogen and gradually merges southward into the Manila Trench in the northernmost part of the South China Sea. Numerous gullies and canyons normal or oblique to the shorelines occur on the sea floors of these two slopes. The inset at the lower right corner shows the plate tectonic settings in the Taiwan region.

(Greene et al., 1989; Eittreim et al., 1989). Similarly, the San Antonio Submarine Canyon on the active margin of the Chile forearc shows that its course is deflected sharply to the north by a prominent structural high of a fault block (Hagen et al., 1996).

\subsection{Shifting of Pliocene-Quaternary canyons}

While studying the structural geometry of the deformation front in the offshore areas of SW Taiwan, Lee et al. (1995) recognized two buried Pliocene-Pleistocene submarine canyons revealed in seismic profiles collected east of the presentday Penghu Canyon. This occurrence suggested westward migration of canyons through time. Buried submarine canyons of Pliocene and Pleistocene age were also found in SW Taiwan by the Chinese Petroleum Company while exploring for hydrocarbons (Fuh et al., 1997, 2003). These authors suggested that these paleo-canyons had shifted southwestward from onshore Taiwan to the present Penghu Submarine Canyon. They further suggested that canyon migration in SW Taiwan can be related to the southward arc-continent collision in Taiwan and accompanied westward movement of thrust fronts.

Although much work has been done, only two studies specifically deal with buried paleo-submarine canyons in SW Taiwan (Fuh et al., 1997, 2003). However, more marine 
surveys have been carried out on the present-day submarine canyons. For instance, the morphology and origin of the present-day Penghu Canyon have been determined (Chuang and Yu, 2002; Yu and Chang, 2002).

\subsection{Purpose}

The recognition of canyon migration in SW Taiwan is a byproduct of the previous studies of Lee et al. (1995) and Fuh et al. (1997, 2003). Their research was not directed at submarine canyons. Therefore, neither a specific model of canyon migration nor possible origins of these paleo-canyons were given. The primary objectives of this paper are to determine the main controls of the location and orientation of the present-day Penghu Canyon with emphasis on the tectonic influence, and to determine the shifting routes of these
Pliocene-Quaternary canyons in relation to evolution of the foreland basin in SW Taiwan.

\subsection{Tectonic setting}

The island of Taiwan is located at the junction of the Ryukyu Arc and the Luzon Arc in the northwestern Pacific (Fig. 1). The Chinese continental margin has obliquely collided with the Luzon Arc during the Late Miocene to present, and has resulted in formation of the Taiwan Island (Suppe, 1981; Ho, 1988). The arc-continental collision is still actively propagating to the south (Suppe, 1987). Accompanying uplift of the Taiwanese fold-and-thrust belt, a foreland basin, has developed west of the Taiwan orogen (Covey, 1984, 1986; Yu and Chou, 2001; Lin and Watts, 2002). This foreland basin contains mainly Pliocene-Pleistocene sediments more than $5 \mathrm{~km}$ thick
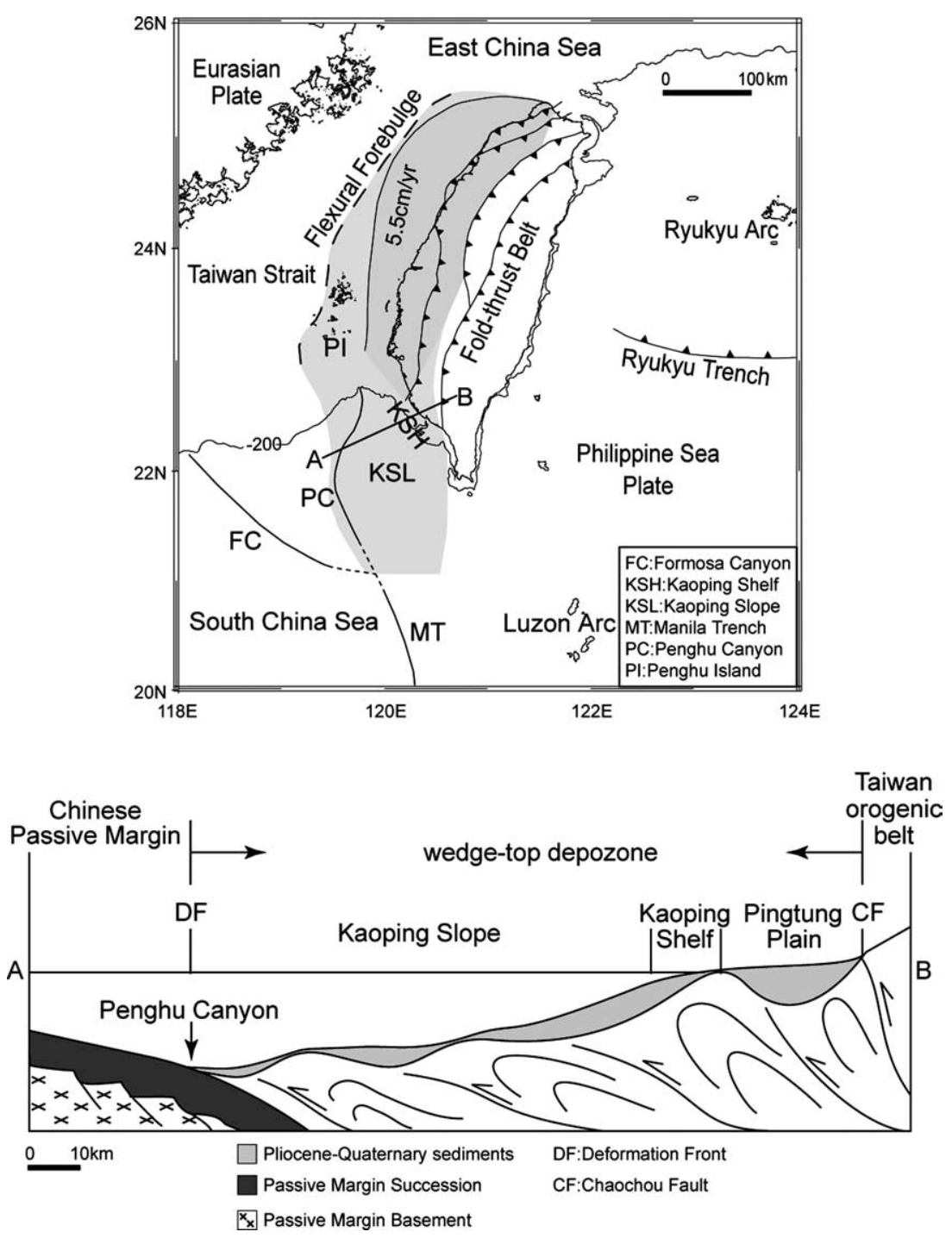

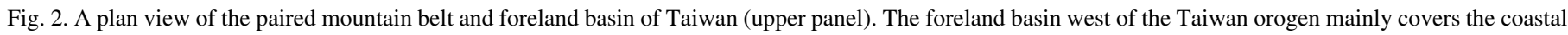

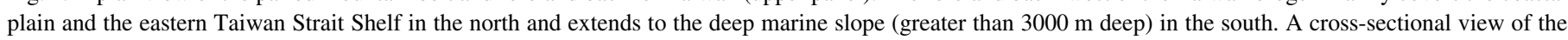

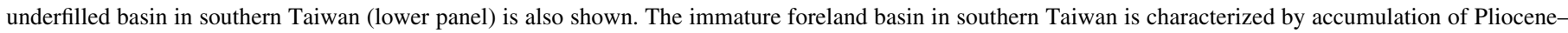

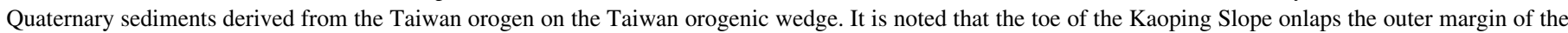
Chinese craton. Modified from Chiang et al. (2004). 
shed from the Taiwan orogen. The western Taiwan foreland basin covers the foothills, coastal plains and offshore areas (Fig. 2). Due to oblique arc-continent collision, the foreland basin west of the Taiwan orogen began earlier in northern Taiwan and then propagated southwestward along the strike of the Taiwan orogen, resulting in a mature foredeep in the north and a youthful under-filled one in the south (Covey, 1984; Sinclair, 1997; Brusset et al., 1999; Chiang et al., 2004). The southern boundary of the young basin is bounded by the continent-ocean boundary north of $21 \mathrm{~N}$. An under-filled foreland basin is referred to as a basin since it has not been filled up to sea level (Sinclair and Allen, 1992).

The shelf and slope of the northernmost South China Sea trend NE-SW, in accordance with the regional structure of the eastern Chinese margin (Fig. 2). The sedimentary sequences of the uppermost part of the Chinese margin consist of PliocenePleistocene, progradational shallow marine sediments that are underlain by block-faulted Early Tertiary strata (Sun, 1982; $\mathrm{Yu}, 1993)$. In contrast, the shelf and slope of the SW Taiwan margin trend NW-SE. The Kaoping shelf-slope regions are mainly composed of Late Pliocene-Holocene sediments derived solely from Taiwan (Chiang, 1998). These young sediments are deformed into thrusts and folds that propagate westward (Yu, 1993; Liu et al., 1997; Lacombe et al., 2001; Chiang et al., 2004). The southwestern Taiwan margin is represented by an active margin.

\section{Data}

Bathymetric and seismic surveys (Fig. 3) off SW Taiwan were carried out from the R/V Ocean Researcher $I$ of the National Taiwan University. The Simrad EK 500 Sonar recorded bathymetric data were integrated into a larger bathymetric data bank compiled by the National Center for Ocean Research, National Taiwan University. The website of the databank is http://www.duck2.oc.ntu.edu.tw. The resulting bathymetric chart (Fig. 1) shows major submarine physiographic features including the Penghu Canyon. An air-gun array was the source for recording four channel seismic reflection profiles. DFS-V floating system is the recording

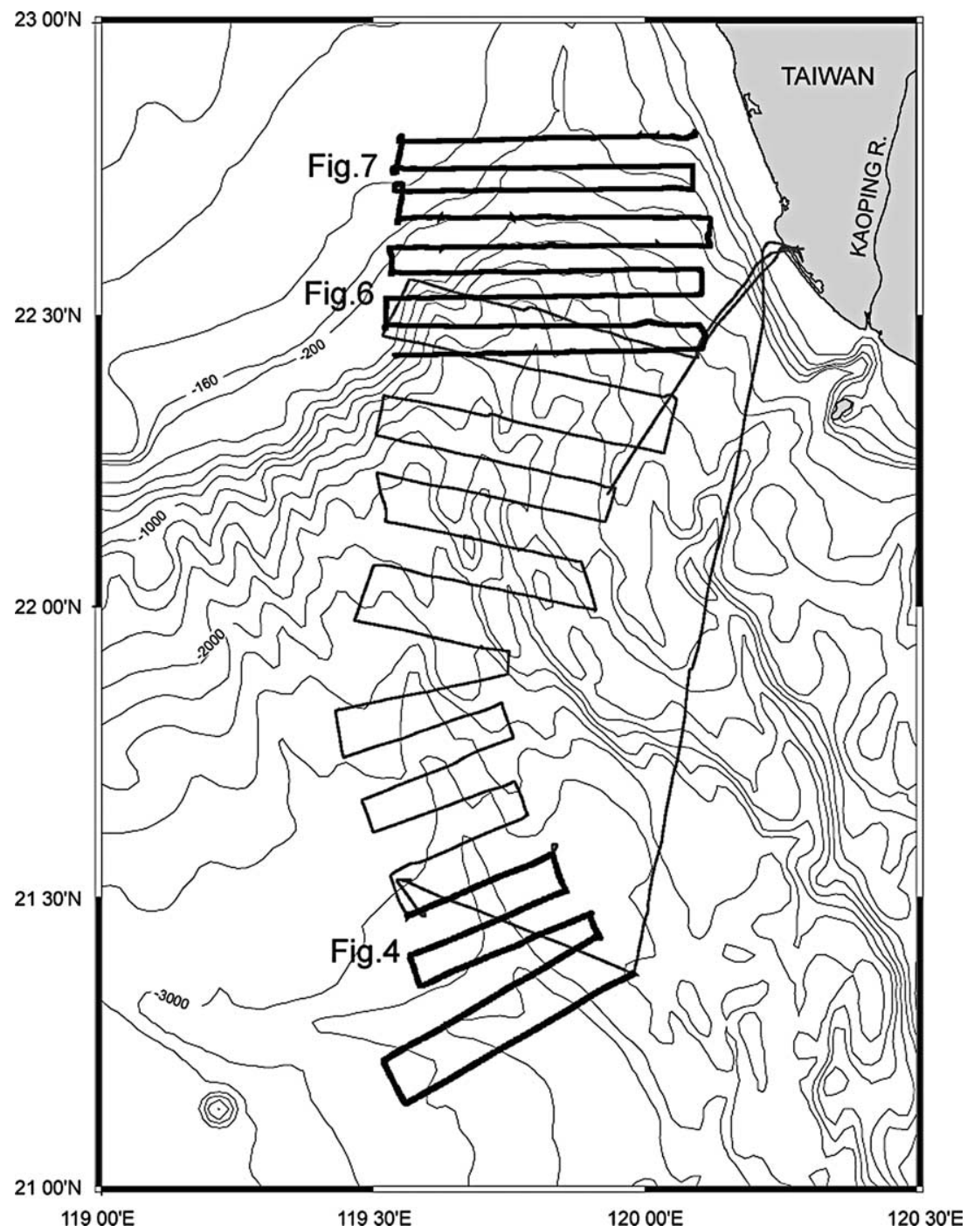

Fig. 3. Map showing bathymetric transects and four-channel seismic profiles covering the upper and lower reaches of the Penghu Canyon. Fourteen seismic profiles (heavy lined) nearly normal to the axis of the Penghu Canyon were acquired. 
device. Marine seismic reflection data were processed using the SIOSEIS system and PROMAX software. A total of 14 seismic reflection profiles, normal to the axis of the Penghu Canyon, were used for seismic interpretations.

\section{Results and discussions}

We first describe the occurrence and seismic expression of the modern Penghu Canyon using updated bathymetric and seismic data, emphasizing the location and orientation of this feature in contrast with other nearby slope canyons. The tectonic controls on the occurrence of this canyon are drawn from an analogous planform kinematic model of foreland basin stratigraphy (Johnson and Beaumont, 1995) and a tectonostratigraphic model for a peripheral foreland basin (Sinclair, 1997). Second, an analogy for longitudinal transport of sediments from the Taiwan orogen via submarine canyons to the nearby deep-water foreland basin is proposed. Third, the shifting routes of these Pliocene-Recent canyons are evaluated in relation to the evolution of the foreland basin in SW Taiwan.

\subsection{Tectonic controls}

The tectonostratigrapic model for underfilled peripheral foreland basins (Sinclair, 1997) is briefly described and then this model is modified and integrated into interpretations of seismic profiles in order to evaluate tectonic influences on the location and orientation of the Penghu Canyon. Sinclair (1997) suggested that sedimentary fills of underfilled foreland basins can be grouped into three basic units through basin evolution. A lower unit consists of carbonates or shallow marine sandstone on the cratonic margin of the basin. The overlying middle unit reflects hemipelagic fall-out of muds offshore from the cratonic margin. The upper unit is dominated by flysch facies, reflecting turbiditic siliciclastic sedimentation on the cratonic margin of the basin. These superimposed stratigraphic units on the cratonic margin of the foreland basin resulted from initial loading of the outer cratonic margin, followed by steady migration of the orogenic wedge toward and over the cratonic margin with syn-tectonic sedimentation (Sinclair, 1997, Fig. 10). Here, we borrow Sinclair's ideas but emphasize tectonics and sedimentation on the orogenic margin of SW Taiwan rather than on the Chinese passive margin. Sequential sediment filling from initiation through growth to nearcompletion in the development of the underfilled foreland basin offshore SW Taiwan is formulated (Fig. 5).

Seismic profile A across the lower reach of the Penghu Canyon in deep-water $(>3000 \mathrm{~m})$ shows that the Penghu Canyon is a shallow trough coinciding with the axis of the foreland basin (Fig. 4). West of the Penghu Canyon is the Chinese margin whose seismic facies in the upper part is characterized by subparallel, low amplitude and moderate, continuous reflections. The lower part shows parallel, continuous and strong reflectors tilting towards the east. East of the canyon lies the Taiwan margin whose seismic patterns consist of chaotic or hummocky reflectors sandwiched between upper and lower reflectors. The seismic characteristics of profile A can be interpreted as representing the initiation of the western Taiwan foreland basin north of the Manila Trench where the frontal orogenic wedge of Taiwan began to override the Chinese margin. The continuous, parallel and strong reflectors resulted from regional thermal subsidence of the Chinese passive margin and deposition of shallow marine sediments during the Late Tertiary (Sun, 1982; Yu and Huang, 1994), characteristics common in the underlying Chinese passive margin. The hummocky reflectors may represent sediment from the Taiwan orogenic wedge being pushed over the toe of the Chinese margin. Little sediment may be



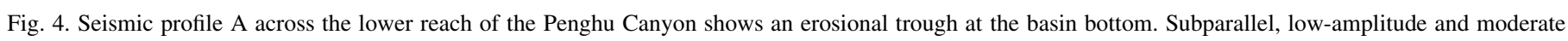

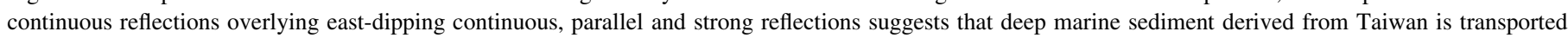

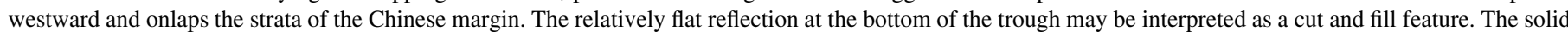

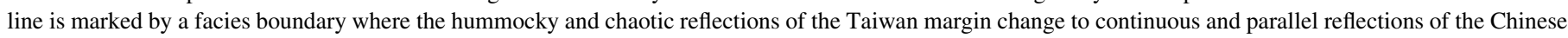
margin. Location of profile A is shown in Fig. 3. 
supplied from the submerged Taiwan orogen due to the low relief of the topographic high. Relatively thin deep-water sediments have accumulated to form a rather flat sea floor at the bottom of the foreland basin as indicated by the upper section of subparallel, low amplitude and moderately continuous reflections. Erosion of the uppermost deep-water sediments from the strata accumulated in the deepest part of the sea floor and formed the Penghu Canyon. Seismic characteristics imply initial infilling of deep-water deposits at the bottom of the foreland with significant room for later fill in the later stage of development (Fig. 5), but is accompanied by minor downcutting at the axis of the foreland basin.

Seismic profile B crosses the upper reaches of the canyon at a water depth of $2200 \mathrm{~m}$. The bottom of the foreland basin is represented by two slopes facing each other representing the

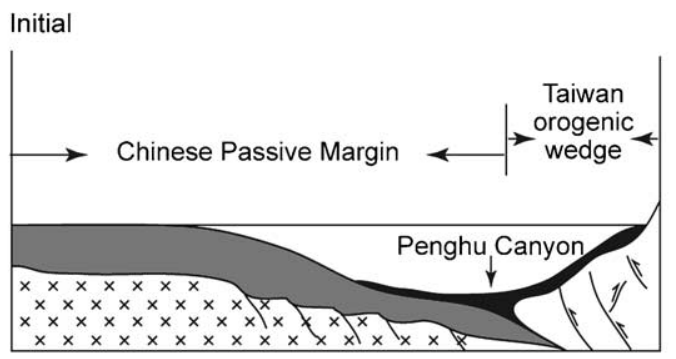

Growth
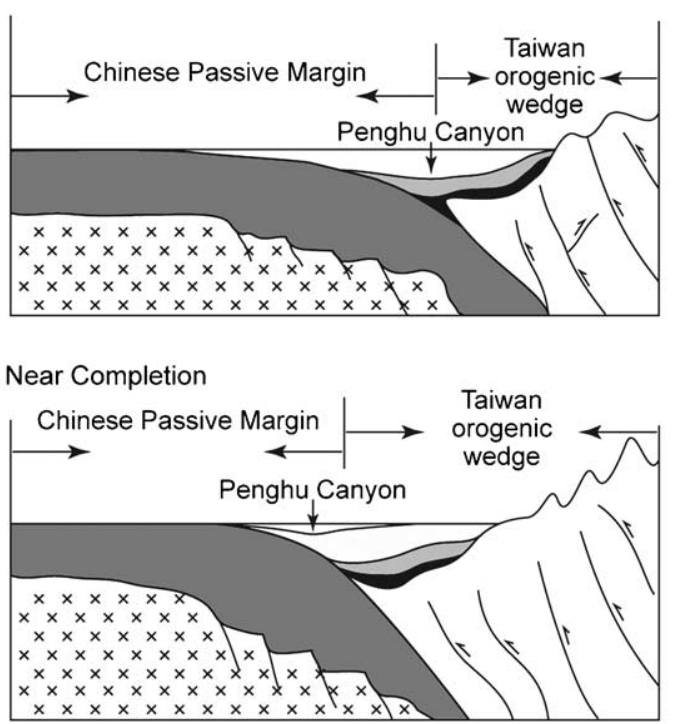

pelagic facies sediments

hemipelagic facies sediments

passive margin succession

neritic sediments

Fig. 5. A general sequential sediment filling model of initiation, growth and near completion of the underfilled foreland basin off southwestern Taiwan. It is noted that sediments derived from Taiwan progressively overlie strata of the Chinese margin, resulting in an increasing thickness of the sediment and shallowing of the basin floor from south to north. The base level of the basin bottom has become higher in the north than in the south due to the sediment filling. The Penghu Canyon is located along the bottom of the basin and resulted from downcutting of the sediments derived from Taiwan following the regional southward dip of the basin axis. Modified from Sinclair (1997, Fig. 10).
Chinese and Taiwanese margins. Distorted and chaotic reflectors prevail (Fig. 6). The seismic patterns suggest that sediments accumulated at the bottom of the foreland basin by gravitational movement and were followed by erosion of gullies and canyons. Continued westward convergence and migration of the Taiwan orogenic wedge over the Chinese margin introduced a larger amount of sediment from the thrust wedge that filled the foreland basin, but with a lesser amount of sediment from the Chinese margin because of the low relief due to flexural uplift (Sinclair, 1997; Yu and Hong, 2002). It is noted that slumping occurred on the sloping surfaces of the toe of the Chinese margin west of the Penghu Canyon and diapiric intrusions occurred on the lower slope of the Taiwan margin east of the canyon (Fig. 6). These sediments are dominated by hemi-pelagic mud as indicated by the presence of mud diapirs that are characteristic structures of the Kaoping slope (Liu et al., 1997). Seismic patterns and sea floor morphology suggest that the foreland basin has received more sediment from the orogenic wedge proximal to the Taiwan mountain range, than from the proto-orogenic wedge distal to the mountain of Taiwan. Profile B also suggests that the foreland basin remains under-filled. The sediment supply does not keep up with the available accommodation space of the foreland basin and therefore the basin is not filled (Fig. 5). The Penghu Canyon rests on sediments mainly derived from Taiwan, suggesting foreland basin sediments overriding the toe of the Chinese margin and being incorporated into the Chinese margin. North-south erosion along the axis of basin formed the modern Penghu Canyon.

Farther up-canyon, seismic profile $\mathrm{C}$ across Penghu Canyon near its head, shows that the Chinese and Taiwan margins have quite different seismic characteristics (Fig. 7). The former has continuous, parallel and divergent reflectors tilting eastwards. In contrast, the Taiwan margin displays discontinuous, lowamplitude and sub-parallel reflectors tilting westwards, representing syn-deformed foreland basin sediments. Taiwanese sediments are advancing westwards and beginning to override the outer shelf and slope of the Chinese margin. This process reflects depression by the Taiwan orogen of the outer Chinese margin. Profile $\mathrm{C}$ also indicates that sediments derived from SW Taiwan have infilled the basin to yield an outer shelf and upper slope setting. Compared to those of profile A, sediment thickness and bathymetry shown on profile $\mathrm{C}$ suggest that the foreland basin has reached a late stage of development of an underfilled basin (Fig. 5). The contact between the frontal strata of the Taiwan margin and the buried Chinese margin is the Penghu Canyon, which is the deepest part of the juxtaposed margins (Fig. 7).

The location and orientation of the Penghu Canyon are mainly controlled by the westward propagation of thrust faults at the tip of the thrust wedge of Taiwan and syn-tectonic foreland sedimentation. Oblique convergence between the Taiwan orogen and the Chinese passive margin from north to south, has resulted in a triangular foreland basin tapering to the north and opening to the south (Fig. 1). This basin consists of two parts: the western flank Chinese passive margin with a northeast regional trend, and the eastern flank active margin of Taiwan with a northwest regional trend. These two margins 


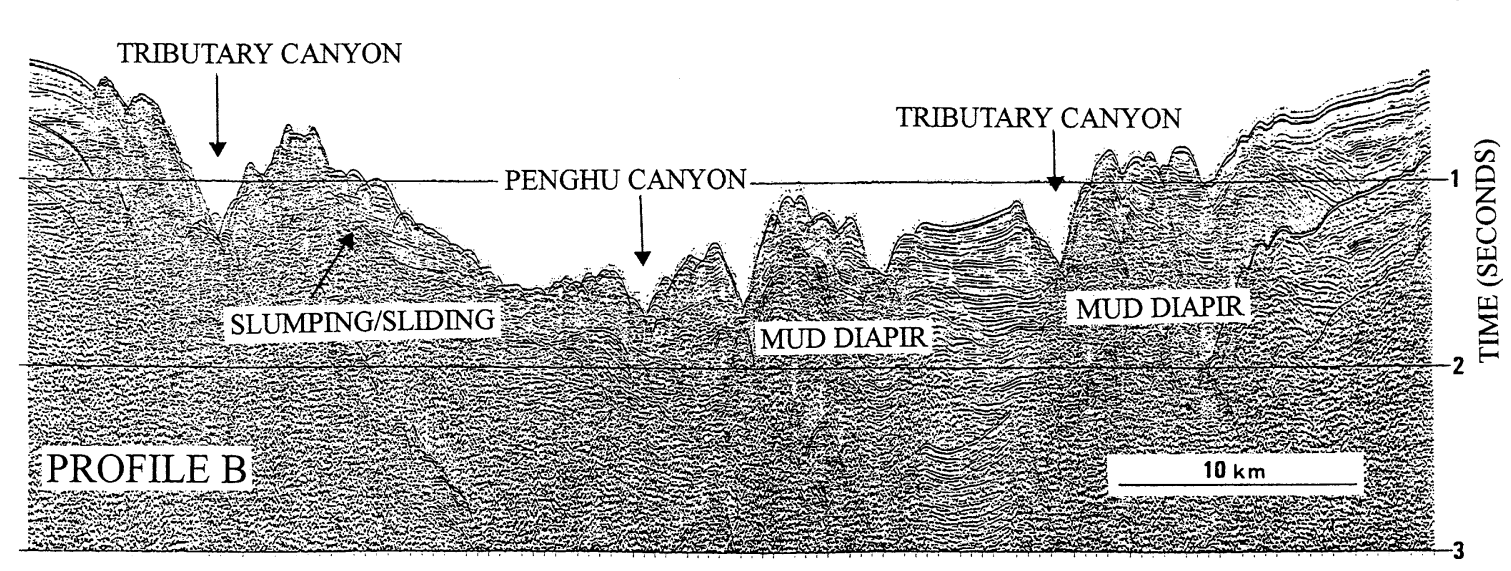

Fig. 6. Seismic profile B shows that sediment at the basin bottom is characterized by chaotic and distorted reflection patterns, resulting from down-slope mass movement with syndepositional deformation. It is noted that Penghu Canyon occurs at the bottom of the basin, although its size is relatively small compared to that of adjacent tributary canyons. The location of profile B is shown in Fig. 3.

converge in the north and enclose two submarine slopes facing each other and marked by outward bowing bathymetric contours (Fig. 1). The basin axis trends and dips towards the south and parallels the strike of the Taiwan orogen, resulting from the continued westward migration of the Taiwan orogen and infilling of the basin by sediments derived from Taiwan. Erosion under the influence of gravity takes place along the axis of the marine basin, following the regional gradient in a north-south direction and forming the present-day Penghu Canyon (Fig. 5).

\subsection{Longitudinal sediment transport via submarine canyons}

In an orogen-foreland basin system, the basin may be filled by different sedimentary processes depending on the along- strike variations of tectonic processes (e.g., orthogonal and oblique collision). Sediments derived from orogens are mainly transported down-slope transversely and deposited in the adjacent basin when two margins converge perpendicularly. When the collision between two margins is oblique, fluvial transport processes consist of short-range transverse hillslope transport and long-range along-strike transport. Fine-grained sediments are mainly longitudinally transported to the marine trough of the basin (Johnson and Beaumont, 1995). However, variations of sediment transport modes are observed in other oblique margins. For example, the Hikurangi margin at the obliquely converging New Zealand plate boundary (Lewis, 1994; Lewis et al., 1998; Lewis and Barnes, 1999). There is along-margin dispersal of suspended load by the mean flow, down-slope dispersal of sediment by turbidity currents and

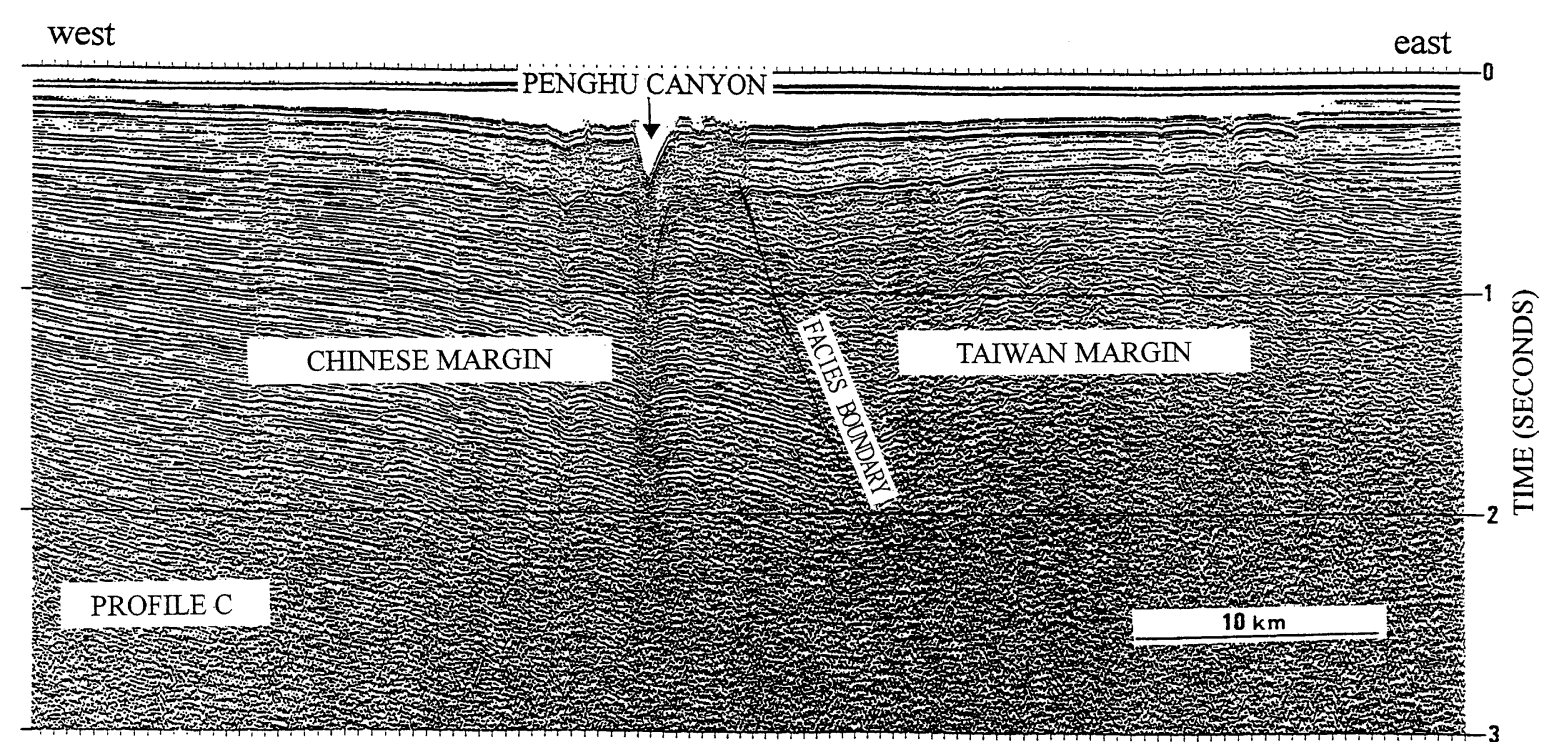

Fig. 7. Seismic profile $\mathrm{C}$ across the upper reach of the Penghu Canyon near its head shows that this canyon is located at the boundary between the Chinese and Taiwan margins and coincident with the basin bottom. The Chinese margin is characterized by continuous, parallel and divergent reflection patterns, whereas the Taiwan margin is characteristic of hummocky and chaotic reflection configurations. The solid line marked facies boundary is the tentative boundary separating these two margins. The location of profile $\mathrm{C}$ is shown in Fig. 3. 
mass movement into subduction troughs and along-margin transport of turbidity currents contained within submarine channels formed within the trough axis. However, this paper suggests that the sedimentary processes of the orogen-foreland basin system in Taiwan with oblique collision can be analogous to the model (Johnson and Beaumont, 1995).

Analyzing lithofacies and ichnofacies in the Foothills of SW Taiwan, Hong (1997) recognized that the present-day Foothills was originally a marine basin with an elongate shape opening towards and becoming deeper to the south with a lower slope and/or basin floor setting that occurred around $1 \mathrm{Ma}$. The exposed Kanshialao Formation of Early Pleistocene age shows mass-gravity facies and channels. Although Hong (1997) did not explicitly mention the longitudinal transport of sediment along the basin axis, we can reasonably suggest that longitudinal sediment transport may have happened along the basin axis (Hong, 1997, Fig. 8).

The modern patterns of river drainage in the Foothills and Coastal Plain, and the distribution of submarine canyons in offshore SW Taiwan, have resulted from common sedimentary processes in a foreland basin formed by oblique collision. It is noticed the Chouhsui River, the largest river in Taiwan, flows in an east-west direction and develops a liner drainage system normal to the Taiwan orogen (Fig. 8). The fluvial transport of sediments from the orogen in central-north Taiwan to the foreland basin is mainly down-slope transversely, reflecting the mature stage of the orogen-foreland basin system. The collision in Taiwan is diachronous and continued for about 5 my along the $400 \mathrm{~km}$ strike of the Taiwan orogen, and it still propagates southward (Suppe, 1987). The collision results in uplifted and steady state of a pair of mountain belts (around $4000 \mathrm{~m}$ high) and an overfilled foreland in central and northern Taiwan, but as a pair of low-relief hills (around $1000 \mathrm{~m} \mathrm{high)} \mathrm{and}$ underfilled foreland basin in southern Taiwan (Covey, 1984, 1986). In central Taiwan, sediments are transported westward far and across the forebulge in the middle of Taiwan Strait and deposited to produce a foothill-coastal plain-shallow shelf (average $60 \mathrm{~m}$ deep) across the overfilled foreland basin (Yu and Chou, 2001).

In contrast, southern Taiwan is at an early collisional stage, and the young orogen has only a small drainage area, and is not producing a great amount of sediment. Sediments from the southern Taiwan orogen cannot reach the forebulge located on the Chinese cratonic margin, resulting in a reduced coastal plain and continental shelf and a deep-water slope topographic profile across the underfilled foreland basin (Fig. 8). It is noted that the Kaoping River, the second largest river in Taiwan, runs along the coastal plain in southern Taiwan in a nearly northsouth direction sub-parallel to the strike of the Taiwan orogen. In the Kaoping Canyon, a major conduit off southwestern Taiwan (Fig. 1), the course extends SW, normal to the shoreline in the shelf-upper slope region. The course then changes to SE parallel to the shoreline. Sediments derived from Taiwan are transported via the Kaoping Canyon, first transversely and later longitudinally. The Penghu Canyon flows from north to south, parallel to the strike of Taiwan oreogen, and characterizes the longitudinal marine transport in an underfilled foreland basin.

The drainage patterns of the Chouhui and Kaoping Rivers and courses of the Kaoping and Penghu canyons suggest that southward progressive uplift and sediment filling along strike of the Taiwan orogen results in different ways for sediment transport. The oblique, diachronous collision resulted in the drainage base level of overfilled foreland basin in central Taiwan to become higher than underfilled basin in southern Taiwan. Progressive uplift of the Taiwan orogen and progradational filling of the foreland basin switched the transverse dip of drainage base level in central Taiwan to the longitudinal direction along strike off southern Taiwan. The course of the Penghu Canyon developed and followed
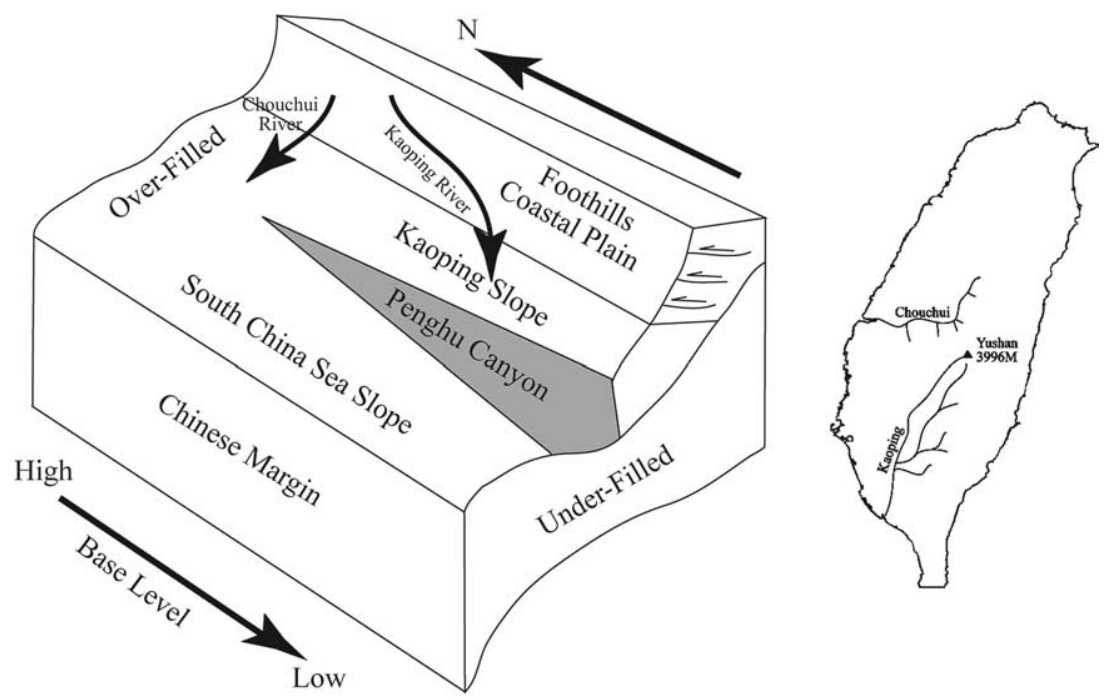

Fig. 8. Schematic drawing of the sediment fill in the underfilled foreland basin off southwestern Taiwan formed by oblique arc-continent collision. The Chouchui River transports sediment transversely and accumulates deposits in an mature foreland basin in central Taiwan. The Kaoping River transports sediment longitudinally and accumulates deposits subaerially to form the coastal plain in southwestern Taiwan. Sediments derived from Taiwan are transported longitudinally farther into the deep marine environment mainly along the basin axis parallel to the strike of the Taiwan orogen. Modified from Johnson and Beaumont (1995). 
the regional dip of the marine drainage in the deep-water slope environments.

Subsequent erosion of the Chinese passive margin did not contribute a significant amount of sediment to the basin due to the low relief by flexural bending. The southern Central Range in the Taiwan flank has a low-relief (about $1000 \mathrm{~m}$ high) and supplies less sediment into the deep-water basin when it is compared to the overfilled foreland basin in northern Taiwan where the Central Range is around 4000 m high (Covey, 1984, 1986). Hence, sediment fluxes from Taiwan and mainland China do not outpace the accommodation space of the basin, resulting in a sediment-starved linear trough. At the same time, continued supply of sediment fed from the Taiwan orogen are transported southward via the Penghu Canyon into the Manila Trench, showing the role of the Penghu Canyon as a conduit for longitudinal sediment transport.

\subsection{Sea level change control}

This section addresses the possible role of sea level change on the formation and orientation of the Pliocene-Pleistocene submarine canyons in the southwestern Taiwan foreland basin. Studying the Pliocene-Pleistocene foreland basin deposits in southwest Taiwan, Chen et al. (2001) recognized five intermediate-stratigraphic sequences that are $150-1000 \mathrm{~m}$ thick and are bounded by unconformities. The unconformities are mainly due to eustatic sea level changes and are correlated to five episodes of major valley incision during 2.3 my depositional history of the foreland basin in southwest Taiwan. However, one of the unconformities with angular relief is evident due to structural uplift and accompanied erosion at about 1.25 Ma and is defined as the sequence boundary at the base of the Kanhsialiao Formation (middle Pleistocene). The duration of individual sequences ranges from about 100 to 700 k.y. Using outcrop data and one seismic profile in the Western Foothill in southwest Taiwan, Chen et al. (2001) did not recognize the presence of submarine canyons in the foreland basin deposits. However, further southwest of the area studied by Chen et al. (2001), buried Pliocene-Pleistocene submarine canyons were recognized by Fuh et al. (2003) using more than $5000 \mathrm{~km}$ long industrial seismic profiles.

As mentioned before, Fuh et al. (2003) did not fully explain the origin of these buried submarine canyons. We carefully examined seismic profiles provided by Fuh et al. (2003, Figs. 3, 4, 10 and 11) and found that submarine canyons mainly occur within an individual stratigraphic sequence, not at the sequence boundaries. For example, nine submarine canyons are identified in the lower and middle parts of the Kanhsialiao Formation. Similarly, other submarine canyons also occur within the individual stratigraphic sequences immediately below or above the Kanhsialiao Formation.

Relative sea level change is the major factor for forming a sequence boundary along continental margins, especially passive ones (Vail, et al., 1977, 1991). A major sea level fall causes exposure of the continental shelf. Intensive erosion on the shelf and upper slope leads to incision of submarine canyons and development of regional unconformities, resulting in the formation of sequence boundaries. Applying Vail's sequence model to explain the canyon in the PliocenePleistocene foreland basin deposits in southwest Taiwan, we expect to see submarine canyons associated with regional unconformities or sequence boundaries. Contrary to Vail's model, submarine canyons are present within the sequences throughout the smaller eustatic cycle of about 37.5 k.y. (Chen et al., 2001). This suggests that local conditions within the stratigraphic sequences of the foreland basin setting are additional factors for canyon incision.

Fuh et al. (2003) pointed out that buried submarine canyons trend more or less in a north-south direction with the maximum width of $5 \mathrm{~km}$ and length of $45 \mathrm{~km}$. The relatively small size and short duration of canyon excavation and infilling indicate that these Pliocene-Pleistocene submarine canyons are local sedimentary features rather than a regional submarine erosional feature. Large submarine canyons have width of tens of $\mathrm{km}$ and length of hundreds of $\mathrm{km}$ and more than millions of years of canyon excavation (Shepard, 1981). In addition, these Pliocene-Pleistocene submarine canyons are distributed laterally within a narrow zone less than $40 \mathrm{~km}$ and progressively younger in age towards southwest (Fuh et al., 2003), reflecting a southwestward progressive migration of the active deformation and foreland basin. Therefore, it appears that PliocenePleistocene canyon excavation and infilling events took place relatively rapidly less than 37.5 k.y. In the active foreland setting of southwest Taiwan, the formation of submarine canyons is mainly influenced by tectonic tilting of the basin
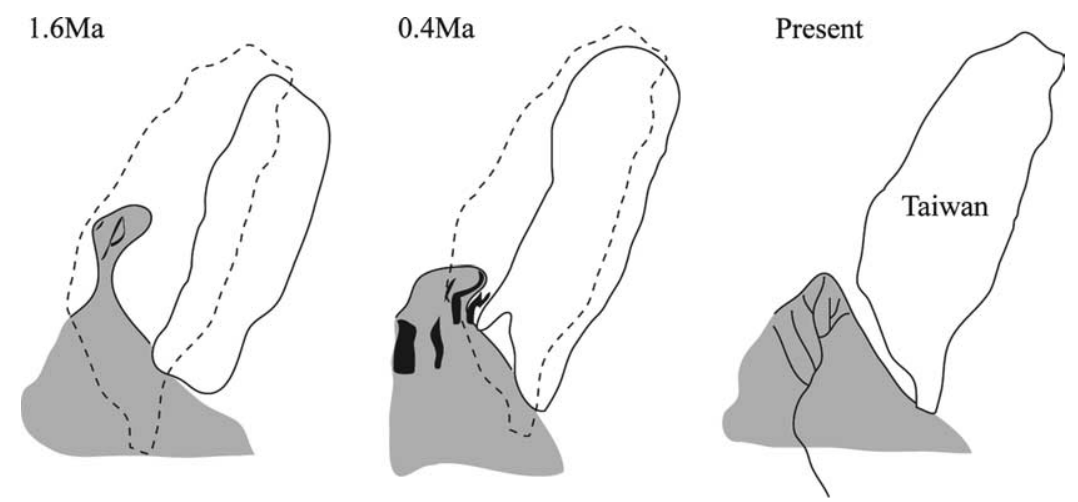

Fig. 9. Paleogeographic maps of the southwestern Taiwan region showing the spatial and temporal distributions of the foreland basins and accompanied submarine canyons from Late Pliocene to the present. Modified from Covey (1984); Lee et al. (1995); Fuh et al. (1997). 
axis, mass-wasting processes induced by increase of slope gradient and structural disturbance rather than regional sea level change.

\subsection{Canyon shifting}

Sequential oblique collision from north to south along the strike of the Taiwan orogen provides a general model for the successive formation of the deep-water foredeeps with submarine canyons along their axial reaches. The submarine canyons are conduits for sediment transported longitudinally from the Taiwan orogen to the foredeep. The paleogeography of foreland basins in Taiwan provides clues for various locations of submarine canyons along the axes of the basins, and hence the canyon shifting routes.

A reconstruction of the western Taiwan foredeep for the past $4 \mathrm{Ma}$ reveals the spatial and temporal evolution of the foreland basin (Fig. 9). Locations of buried PliocenePleistocene canyons in southwestern Taiwan (Fuh et al., 1997, 2003; Lee et al., 1995) are then superimposed on the successive foredeeps and the canyon shifting routes become apparent (Fig. 9). During the Early Pleistocene, approximately 1.6 Ma ago, the Taiwan foredeep was formed as a narrow trough parallel to the strike of the east flanking orogen. Several submarine canyons developed in the northern parts of the deep trough where the shallow shelf transitions to upper slope facies southwards. Downslope erosion of slope sediments under the longitudinal sediment transport system with the evolving foredeep, formed approximately north-south trending canyons. At about 0.4 Ma, the basin and associated marine facies continued to subside southwestwards to occupy a wider area than in the Pliocene. Similarly, several submarine canyons of Late Pleistocene age developed in the northern part of the basin under a south-dipping upper slope setting. The present-day Penghu Canyon and its tributary canyons occur in the upper reaches of the present western Taiwan foredeep. The shifting of axis of these Pliocene-Recent submarine canyons in southwestern Taiwan reflect the evolving deep marine foreland basin and longitudinal submarine canyon transport system.

\section{Conclusions}

The bathymetry shows that, although the Penghu Canyon runs along the intersection of the toes of the South China Sea and Kaoping Slopes, it has the tributary heads at both the South China Sea and Kaoping Slopes. The Penghu Canyon excavates along the axis of the underfilled foreland basin off southwestern Taiwan and its main course flows southwards and parallel to the strike of the Taiwan orogen. The location and orientation of the Penghu Canyon lead us to conclude that this canyon has a composite origin with tectonic controls prevalent over sedimentary processes. The tectonics controls the orientation of the Penghu Canyon. However, down-slope processes are important components in its excavation and modification.

Due to oblique arc-continent collision, the western Taiwan foredeep has evolved into a mature, overfilled northern basin and an immature, underfilled southern one. During the evolution, deep foreland basins were formed with longitudinal sediment transport from north to south following the regional southward dipping trend. The axes of the progressively younger foredeeps were the locations of submarine canyons aligned with the strike of the Taiwan orogen. Shifting of canyon axes from northeast to southwest reflect the parallel foredeep evolution in western Taiwan. The linkage of canyon migration with the evolution of the foreland basin may have significant implications for the overall sedimentation and tectonics of the SW Taiwan region.

\section{Acknowledgments}

We would like to thank the captain, crew and technicians who helped to collect the data onboard R/V Ocean Research I of the National Taiwan University. This project was supported by the National Science Council, Taiwan. Lionel Carter reviewed the early version of the manuscript and gave constructive comments. Kevin Burke polished the English grammar and made the manuscript more readable.

\section{References}

Brusset, S., Deramond, J., Souquet, P., Mouthereau, F., Deffontaines, B., 1999. Pro-foreland basin system linked to Taiwan mountain building. Active subduction and collision in southeast asia: data and models, International Conference and Fourth France-Taiwan Symposium, Montpellier, France, Program and Extended Abstract, 67-68.

Chen, W.S., Ridgway, K.D., Horng, C.S., Chen, Y.K., Shea, K.S., Yeh, M.G., 2001. Stratigraphic architecture, magnetostratigraphy, and incised-valley systems of the Pliocene-Pleistocene collisional marine foreland basin of Taiwan. GSA Bull. 113, 1249-1271.

Chiang, C.S., 1998. Tectonic Features of the Kaoping Shelf-Slope Region off Southwestern Taiwan: Wedge-top Depozne. National Taiwan University, PhD Thesis, 130pp.

Chiang, C.S., Yu, H.S., Chou, Y.W., 2004. Characteristics of the wedgetop depozone of the southern Taiwan foreland basin system. Basin Res. 16, 65-78.

Chuang, C.Y., Yu, H.S., 2002. Morphology and canyon forming processes of upper reach of the Penghu Submarine Canyon off southwestern Taiwan. Terr. Atmos. Oceanic Sci. 13, 91-108.

Covey, M., 1984. Lithofacies analysis and basin reconstruction, PlioPleistocene western Taiwan foredeep. Pet. Geol. Taiwan 20, 53-83.

Covey, M., 1986. The evolution of foreland basin to steady state: evidence from the western Taiwan foreland basin. Spec. Publ. Int. Ass. Sediment 8, 77-90.

Eittreim, S.L., Embley, R.W., Normark, W.R., Greene, H.G., McHugh, C.M., Ryan, B.F., 1989. Observations in Monterey Canyon and Fan Valley Using the Submersible ALVIN and a Photographic Sled. USGS Open-File Report, 89-291.

Fuh, S.C., Liu, C.S., Wu, M.S., 1997. Migration of canyon systems from Pliocene to Pleistocene in area between Hsyning structure and Kaoping Slope and its application for hydrocarbon exploration. Pet. Geol. Taiwan 31, 43-60.

Fuh, S.C., Liang, S.C., Wu, M.S., 2003. Spatial and temporal evolution of the Plio-Pleistocene submarine canyons between Potzu and Tainan, Taiwan. Pet. Geol. Taiwan 36, 1-18.

Greene, H.G., Stubblefield, W.L., Thebergc, A.E., 1989. Geology of the Monterey submarine canyon system and adjacent areas, offshore central California. USGS Open-File Report, 89-221.

Hagen, R.A., Vergara, H., Naar, D.F., 1996. Morphology of San Antionio submarine canyon on the central Chile forearc. Mar. Geol. 129, 197-205. 
Ho, C.S., 1988. An introduction to the geology of Taiwan: explanatory text for geologic map of Taiwan. Ministry of Economic Affairs, Republic of China, Taipei, Taiwan. 192pp.

Hong, E., 1997. Evolution of Pliocene to Pleistocene sedimentary environments in an arc-continent collision zone: evidence from the analysis of lithofacies and ichnofacies in the southwestern foothills of Taiwan. J. Asian Earth Sci. 15, 381-392.

Johnson, D.D., Beaumont, C., 1995. Preliminary results from a planform kinematic model of orogen evolution, surface processes and the development of clastic foreland basin stratigraphy. In: Dorobek, S.L., Ross, G.M. (Eds.), Stratigraphic Evolution of Foreland Basins SEPM, Special Publ., No. 52, Tulsa, Oklahoma, USA, pp. 3-24.

Lacombe, O., Mouthereau, F., Angelier, J., Deffontaines, B., 2001. Structural, geodetic and seismological evidence for tectonic escape in SW Taiwan. Tectonophysics 333, 323-345.

Lee, T.Y., Hsu, Y.Y., Tang, C.H., 1995. Structural geology of the deformed front between $22 \mathrm{~N}$ and $23 \mathrm{~N}$ and migration of the Penghu canyon, offshore southwestern Taiwan arc-continent collision zone. International Conference and Third Sino-French Symposium on Active Collision in Taiwan, extended abstract, 219-227.

Lewis, K.B., 1994. The 1500-km-long Hikurangi Channel: trench-axis channel that escapes it trench, crosses a plateau, and feeds a fan drift. Geo-Mar. Lett. 14, 19-28.

Lewis, K.B., Barnes, P.M., 1999. Kalikoura Canyon, New Zealand: active conduit form near-shore sediment zones to trench-axis channel. Mar. Geol. $162,39-69$.

Lewis, K.B., Collot, J.Y., Lallemand, S.E., 1998. The dammed Hikurangi Trough: a channel-fed trench blocked by subducting seamounts and their wake avalanches (New Zealand-France GeodyNZ Project). Basin Res. 10, 441-468.

Lin, A.T., Watts, A.B., 2002. Origin of the West Taiwan basin by orogenic loading and flexure of a rifted continental margin. J. Geophys. Res. 107, 1029-1048.

Liu, C.S., Huang, I.L., Teng, L.S., 1997. Structural features off southwestern Taiwan. Mar. Geol. 137, 305-319.

McHugh, C., Ryan, B.F., Eittreim, S., Reed, D., 1998. The influence of the San Gregorio fault on the morphology of Monterey Canyon. Mar. Geol. 146, 63-91.
Pratson, L.F., Coakley, B.J., 1996. A model for the headward erosion of submarine canyons induced by downslope eroding sediment flows. Geol. Soc. Am. Bull. 108, 225-234.

Shepard, F.P., 1981. Submarine canyons: multiple causes and long term perspective. AAPG Bull. 65, 1062-1077.

Sinclair, H.D., 1997. Tectonostratigraphic model for underfilled peripheral foreland basins: an alpine perspective. GSA Bull. 109, 324-346.

Sinclair, H.D., Allen, P.S., 1992. Vertical versus horizontal motions in the Alpine orogenic wedge: stratigraphic response in the foreland basin. Basin Res. 4, 215-232.

Sun, S.C., 1982. The Tertiary basin of offshore Taiwan. Proceedings of Second ASCOPE Conference and Exhibition, Manila, Philippines, 126-135.

Suppe, J., 1981. Mechanics of mountain building and metamorphism in Taiwan. Geol. Soc. China Mem. 4, 67-89.

Suppe, J., 1987. The active Taiwan mountain belt. In: Schaer, J.-P. Schaer, Rodgers, J., (Eds.), Comparative Anatomy of Mountain Ranges. Princeton University Press, Princeton, NJ, pp. 277-293.

Vail, P.R., Mitchum, R.M., Thompson, S., 1977. Seismic stratigraphy and global changes of sea level, Part 4: global cycles of relative changes of sea level. In: Payton, C.E. (Ed.), Seismic Stratigraphy-Applications to Hydrocarbon Exploration Am. Assoc. Pet. Geol. Mem. 26, Tulsa, Oklahoma, USA, pp. 83-97.

Vail, P.R., Audemard, F., Bowman, S.A., Eisner, P.N., Perezcruz, C., 1991. The stratigraphic signature of tectonics, eustacy and sedimentology - an overview. In: Einsele, G., Ricken, W., Seilacher, A. (Eds.), Cycles and Events in Stratigraphy. Springer, Berlin, pp. 618-659.

Yu, H.S., 1993. Contrasting tectonic style of a foredeep with a passive margin: Southwest Taiwan and South China. Pet. Geol. Taiwan 28, 97-118.

Yu, H.S., Chang, J.F., 2002. The Penghu Submarine Canyon off southwestern Taiwan: morphology and origin. Terr. Atmos. Oceanic Sci. 13, 547-562.

Yu, H.S., Chou, Y.W., 2001. Characteristics and development of the flexural forebulge and basal unconformity of Western Taiwan Foreland Basin. Tectonophysics 333, 277-291.

Yu, H.S., Huang, F.W., 1994. Stratigraphy of Cenozoic sequences in Taiwan Strait and southern East China Sea. Pet. Geol. Taiwan 29, 171-192.

Yu, H.S., Hong, E., 2002. Foreland sedimentation, longitudinal sediment transport and shifting submarine canyon in a remnant marginal sea off SW Taiwan, AGU Chapman Conference on Continent-Ocean Interactions within East Asian Marginal Sea, San Diego, CA, November 11-14, abstract. 